\title{
Does adaptive marketing capabilities mediate the association between market orientation and marketing performance?
}

\author{
Maryanti, A.S. Hussein \& K. Ratnawati \\ Brawijaya University, Malang, Indonesia
}

\begin{abstract}
SMEs, which play a very important role in the improvement of the Indonesian economy, have been rapidly growing every year. One of the industrial sectors that is growing rapidly is the creative industry. Therefore, the purpose of this research is to examine the link between market orientation and marketing performance through adaptive marketing capabilities. A self-administered survey was conducted targeting SMEs in the creative industry sector in Malang, East Java. Two hypotheses were tested using SmartPLS 3.0. The results demonstrate that adaptive marketing capabilities did not mediate the relationship between market orientation and marketing performance.
\end{abstract}

\section{INTRODUCTION}

\subsection{Background}

The growth of small and medium enterprises (UKM), which has been occurring every year, has been able to improve the Indonesian economy. The creative industry also cannot be separated from this, which has also been growing rapidly recently. The 2018 World Conference Creative Economy stated that the creative industry sector in Indonesia has contributed 852 trillion Rupiah to the gross domestic product (GDP) or equivalent to 7.3 percent of Indonesia's total GDP over the last three years.

Based on presidential regulation number 72 of 2015 , there are 16 creative industry sub-sectors, out of which there are three sub-sectors that dominate with a percentage above 10 percent: culinary with a percentage of $41.69 \%$, fashion at $18.15 \%$, and crafts at $15.07 \%$. Meanwhile, there are subsectors that are growing rapidly. They are visual communication design, music, video animation, and architecture.

Through the R-A theory, market orientation is identified as a source of competitive advantage and innovation as a supporting tool in maintaining competitiveness. Market orientation basically requires innovative steps in accordance with market conditions and consumer expectations; therefore, market orientation is seen as an innovative action. The most important thing in marketing is to meet the needs of customers, which can be achieved through innovative practices in the creation of new goods and services, so as to achieve superior performance as directed by organizations in the market. (Remli et al., 2013; Pardi et al., 2014).

To always be able to contribute to the regional economy, SMEs must have a good performance. With a good performance, SMEs will be able to survive, grow, and develop. Marketing performance is one of the keys to the success of SMEs with intense business competition. The high marketing performance of a business will provide a large advantage for SMEs. Therefore, it is important for an SME to improve its marketing performance.

In the midst of rapidly changing business conditions, SMEs are required to be able to accommodate these changes. Therefore, the concept of marketing capability cannot be fully applied. It is necessary to develop a concept of adaptive marketing capabilities. From the point of view of satisfying customer needs, traditional marketing management has usually focused exclusively 
on reactively meeting explicit customer needs, while ignoring latent or implicit demand (Miles \& Darroch, 2004; Guo, H. et al, 2018). The novelty in this paper is the developing concept of adaptive marketing capabilities as stated by Guo, $\mathrm{H}$. et al, who observed that instead of being reactive to change, the new function of marketing capabilities (adaptive marketing capabilities) is to anticipate, identify, and explore customers' explicit and implicit needs and sometimes even create change in the external environment (Guo, H. et al, 2018). The purpose of this research is to investigate the effect of market orientation on marketing performance and to investigate the effect of market orientation on marketing performance through adaptive marketing capabilities.

\section{LITERATURE REVIEW}

\section{$2.1 \quad R A$ theory and industrial competition}

Competition can be seen as a process that focuses on the market position with regard to competitive advantage. Continuous advantage will be achieved if the company continues to invest in and accumulate resources and competitors fail to replicate these resources because they are protected by patents, are socially complex, and/or exhibit a decline in economic time. Innovation is crucial to competition and growth (O'Keeffe et al., 1998).

\subsection{Market orientation}

An organization's market orientation helps the management to identify consumers whose value requirements best serve the organization's unique capabilities. Market-oriented organizations continue to gather information on consumers, competitors, and markets; view information from an overall business perspective; decide how to deliver superior consumer value; and take action to provide value to consumers (Craven, 2006).

Wang (2009) defines market orientation as a set of behaviors that refers to the collection of intelligence on customer needs and external forces that shape those needs (intelligence generation), the extent to which the external intelligence obtained is disseminated within the company (intelligence dissemination), and actions that are taken in response to external intelligence generated and disseminated (responsiveness).

\subsection{Adaptive marketing capabilities}

Adaptive marketing capabilities can be defined as capabilities that can be extended proactively to sense and act on market signals, continue to learn from market experiments and integrate and coordinate social network resources to adapt to market changes, and predict industry trends (Guo et al., 2018). Adaptive marketing capabilities are the company's ability to identify and take advantage of the emerging market opportunities, and the development of adaptive capabilities is often accompanied by the evolution of organizational forms (Polat and Akgün, 2015).

\subsection{Marketing performance}

Voss and Voss (2000) state that marketing performance can be defined as a business measure of the company's success rate, including sales turnover, number of customers, profits, and sales growth. Companies want to achieve better marketing performances to make them more effective and increase market share and profitability (Utaminingsih, 2016).

\section{RESEARCH METHODOLOGY}

\subsection{Data collection}

The relationship between market orientation and marketing performance and the mediating effect of adaptive marketing capabilities were investigated. A self-administered survey was conducted 
targeting SMEs in the creative industry sector in Malang, East Java. The population in this study is SMEs engaged in the creative industry sector in Malang. Non-probability techniques with a purposive method were applied in this study because there were no official records related to the exact number of creative industry actors in Malang. The criteria used in this study are as follows:

1. Businesses that are classified as small and medium-sized business.

2. Businesses that have been running for at least two years continuously.

A total of 100 respondents were involved in the quantitative inquiry, but only 68 could be used for further analysis. From 16 subsectors of the creative industry, only 9 subsectors could be involved in this research. They are advertising, culinary, fashion, handicraft, photography, product design, visual arts, application and game developer, and visual communication design. There were more females than males, and about 66.2 percent of the respondents were young adults. Almost half of the respondents were high school graduates. 41.2 percent of the respondents had 2-5 years of business experience, and nearly 50 percent of the respondents had a turnover of under 10 million Rupiah per month.

\section{FINDINGS}

\subsection{Convergent validity}

The convergent value is the value found in each loading factor in the relationship of latent variables with indicators, which is expected to be greater than 0.6 .

Table 1. Convergent validity

\begin{tabular}{lll}
\hline Indicator & Convergent validity & Conclusion \\
\hline MO01 & 0.662 & Valid \\
MO02 & 0.717 & Valid \\
MO03 & 0.805 & Valid \\
MO04 & 0.653 & Valid \\
MO06 & 0.668 & Valid \\
AMC01 & 0.654 & Valid \\
AMC06 & 0.661 & Valid \\
AMC07 & 0.728 & Valid \\
AMC08 & 0.742 & Valid \\
MP01 & 0.842 & Valid \\
MP02 & 0.932 & Valid \\
MP03 & 0.880 & Valid \\
\hline
\end{tabular}

Source: Primary Data Processed, 2020

Based on Table 1, it is revealed that all the indicators have a good validity value, and thus it is implied that these indicators can measure their variables.

\subsection{Average Variance Extracted (AVE)}

Average variance extracted (AVE) on the variable market orientation $(0.513>0.5)$, adaptive marketing capabilities $(0.550>0.5)$ and marketing performance variables $(0.784>0.5)$ is obtained, and it can be seen that all constructs have met the criteria (Table 2). 
Table 2. Average Variance Extracted (AVE)

\begin{tabular}{ll}
\hline Variables & Average Variance Extracted (AVE) \\
\hline Market Orientation & 0.513 \\
Adaptive Marketing Capabilities & 0.550 \\
Marketing Performance & 0.784 \\
\hline
\end{tabular}

Source: Primary Data Processed, 2020

\subsection{Cronbach's Alpha}

The reliability test can also be strengthened with Cronbach's Alpha. Table 3 shows that the Cronbach's Alpha value for all constructs is above 0.7 ; for market orientation, it is 0.758 ; for adaptive marketing capabilities, it is 0.720 ; and for marketing performance, it is about 0.863 . The results show that all variables are reliable.

Table 3. Cronbach's Alpha

\begin{tabular}{ll}
\hline Variables & Cronbach's Alpha \\
\hline Market Orientation & 0.513 \\
Adaptive Marketing Capabilities & 0.550 \\
Marketing Performance & 0.784 \\
\hline
\end{tabular}

Source: Primary Data Processed, 2020

\subsection{Coefficient of determination}

The result of this study shows that market orientation and adaptive marketing capabilities influence marketing performance with $\mathrm{R} 2=0.317$. This means that market orientation and adaptive marketing capabilities have an effect on marketing performance.

\subsection{Result of hypotheses}

Table 4 shows that the relationship between market orientation and marketing performance is significant with a $\mathrm{T}$ statistic of 2.187 (>1.96). The p-values are smaller than $0.05(0.029)$. Thus, $\mathrm{H} 1$, which states that market orientation affects marketing performance, is accepted. Adaptive marketing capabilities as the mediating variable cannot affect the relationship between market orientation and marketing performance because the score of the T statistic is $0.584(<1.96)$. The $\mathrm{p}$-values are greater than $0.05(0.560)$. Thus, $\mathrm{H} 2$, which states that market orientation affects marketing performance through adaptive marketing performance, is rejected.

Table 4. Result of hypotheses

\begin{tabular}{llll}
\hline & T Statistics & P-Values & Result \\
\hline $\mathrm{MO} \rightarrow \mathrm{MP}$ & 2.187 & 0.029 & Accepted \\
$\mathrm{MO} \rightarrow \mathrm{AMC} \rightarrow \mathrm{MP}$ & 0.584 & 0.560 & Rejected \\
\hline
\end{tabular}

Source: Primary Data Processed, 2020 


\section{CONCLUSION}

This research has shown that an increase in marketing performance can occur when there is an increase in market orientation, but adaptive marketing capabilities could not increase marketing performance. As with any studies, there are some drawbacks in this research such as the samples chosen were limited to the SMEs in the creative industry sector and not all the subsectors were involved in this research. Thus, future studies are suggested to cover all the subsectors in the creative industry and select more sectors and also other variables that are related to marketing performance.

\section{REFERENCES}

Guo, H., Xu, H., Tang, C., Liu-Thompkins, Y., Guo, Z., \& Dong, B. (2018). Comparing the impact of different marketing capabilities: Empirical evidence from B2B firms in China. Journal of Business Research, 93(May 2017), 79-89. https://doi.org/10.1016/j.jbusres.2018.04.010

Merrilees, B., Rundle-Thiele, S., \& Lye, A. (2011). "Marketing capabilities: Antecedents and implications for B2B SME performance". Industrial Marketing Management, 40(3),368-375. https://doi.org/ https://doi.org/10.1016/j.indmarman.2010.08 005

O'Keeffe, M., Mavondo, F., \& Schroder, B. (1998). the Resource-Advantage Theory of Competition: Implications for Australian Agribusiness. Agribusiness Perspective Papers, 2, 1-13.

Utaminingsih, A. (2016). MEDIA EKONOMI DAN MANAJEMEN Vol. 30 No. 2 Juli 2015. Media Ekonomi Dan Manajemen, 30(2), 161-177.

(2019, Oktober 19). Retrieved from BEKRAF: https://www.bekraf.go.id/pustaka/page/data-statistik-danhasil-survei-khusus-ekonomi-kreatif

(2019, Oktober 19). Retrieved from Departemen Koperasi: http://www.depkop.go.id/uploads/tx_rtgfiles/ SANDINGAN_DATA_UMKM_2012-2017_.pdf

(2019, Nopember 14). Retrieved from Malang Merdeka: https://malang.merdeka.com/kabar-malang/kotamalang-terpilih-sebagai-kota-kreatif-indonesia-190626w.html

(2019, Nopember 25). Retrieved from Badan Pusat Statistik Malang: https://malangkota.bps.go.id/ statictable/2017/06/14/537/luas-wilayah-dan-persentase-luas-wilayah-di-kota-malang-terhadap-luas-kotamalang.html

(2019, Desember 11). Retrieved from PMK3I: https://www.kotakreatif.id/16-subsektor 